\title{
Serological and molecular techniques for the diagnosis of Brucellosis
}

\author{
Mujeeb ur Rahman ${ }^{1, *}$, Amir Ullah $^{2}$, Haroon $^{3}$, Muhammad Bilal $^{4}$, Fazal Mehmood Khan ${ }^{5}$, Muhammad Naveed $^{6}$
}

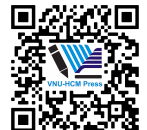

Use your smartphone to scan this QR code and download this article

${ }^{1}$ College of Life Science, Northwest University, Xian, Shaanxi, P.R China 710069

${ }^{2}$ Department of Microbiology, Hazara University, Mansehra, Khyber Pakhtunkhwa, Pakistan Amir Ullah

${ }^{3}$ College of life science, Northwest University, Xian, Shaanxi, China

${ }^{4}$ College of biotechnology, Tianjin University of Science and Technology, Tianjin

${ }^{5}$ Center for Emerging Infectious Diseases, Wuhan Institute of Virology, Chinese Academy of Sciences, Wuhan 430071 China

${ }^{6}$ Department of Microbiology, Hazara University, Mansehra, Khyber

Pakhtunkhwa, Pakistan

Correspondence

Mujeeb ur Rahman, College of Life Science, Northwest University, Xi'an, Shaanxi, P.R China 710069

Email: mujeeb@stumail.nwu.edu.cn

History

- Received: 2019-08-31

- Accepted: 2019-11-21

- Published: 2019-12-31

DOI : 10.32508/stdj.v22i4.1709

\section{Check for updates}

\section{Copyright}

(c) VNU-HCM Press. This is an openaccess article distributed under the terms of the Creative Commons Attribution 4.0 International license.

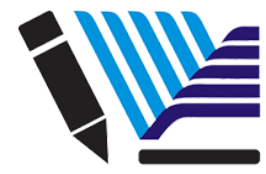

VNU-HCM Press

\begin{abstract}
Brucellosis is known as undulant fever or Malta fever, caused by the genus Brucella. It is the most common human zoonosis. The disease is worldwide distributed and causes significant economic losses. In animals, it causes abortion, reduction in milk production, and infertility. While brucellosis in humans is a debilitating disease with various clinical manifestations that may lead to death in some cases. Control of disease in animals needs proper diagnosis, permanent monitoring of brucellosisfree herds, and removal of infected animals. The current review will discuss the serological and molecular techniques daily used for the determination of brucellosis in animals and humans.
\end{abstract}

Key words: Brucellosis, Serological, Molecular, Diagnosis, Tests

\section{INTRODUCTION}

Human Brucellosis is a significant zoonosis with a worldwide geographical distribution. The causative agents of brucellosis belong to the genus Brucella. The traditional human's disease generally caused by $B$. melitensis, B. abortus, and B. suis. Brucellosis mostly transmitted to humans through direct contact with infected animal secretions, placentas, or aborted fetuses and by the consumption of unpasteurized milk and milk products. In cattle, brucellosis causes reduce fertility, stillbirth, late birth, and reduced milk production resulting in significant economic losses. While in humans, its clinical manifestations are nonspecific such as undulant fever, insomnia, malaise, nervousness, repression, and sexual impotence. Brucellosis in humans is also known for various organ involvement, causing meningitis, encephalitis, endocarditis, orchitis, arthritis, and prostatitis. Additionally, in pregnant women, brucellosis causes spontaneous abortions ${ }^{1}$.

It is challenging to diagnose brucellosis because signs and symptoms are almost similar to other infections; the causative agent usually grows very slowly in blood culture, and also the serodiagnosis is complicated ${ }^{2}$. Brucellosis can be diagnosed by using several serological tests using Brucella antibodies, but the gold standard remains isolation and identification of the bacterium. Cultural observations of Brucella are time consumable, non-sensitive, and hazardous to lab staff. Various attempts were made to diagnose brucellosis for more than one century. Brucella diagnosed by using a combination of tests to avoid false-negative results $^{3}$.
Therefore, this study aims to review diagnostic techniques used for the isolation, screening, epidemiological surveillance, and confirmatory for brucellosis in humans and livestock.

\section{DIRECT SMEAR MICROSCOPIC EXAMINATION}

The microorganism can be identified by microscopic examination of stained smear from secretions, fetuses, and exudates like vaginal discharges, placenta, using modified Ziehl-Neelsen (ZN) staining. This can provide a predictive diagnosis of brucellosis, especially with serological support. Brucellae are not a true acidfast bacillus but show resistant to decolorization by week acids. They seem like short rods or coccobacilli, mostly arranged singly but occasionally in pairs or small groups. They appear as coccobacilli or short rods, usually arranged individually but sometimes in pairs or small groups. Organisms such as Chlamydia abortus and Coxiella burnetii can resemble Brucella. The diagnoses of Brucella can sometimes be misleading by Coxiella burnetti, Chlamydophila abortus, and Chlamydia psittaci because these bacterial strains are superficially similar to Brucella strains ${ }^{4}$. To identify and isolate B. melitensis accurately it is best to used vaginal swab and milk samples of goats and sheep and culture these samples on culture media Farrell,s selective media ${ }^{5}$.

\section{CULTURAL ISOLATION OF BRUCELLA ORGANISM}

Brucella may be isolated from the placenta, fetus, vaginal swab, colostrum, milk, semen, the secretion 
of nonlactating udders, the testis and the sites of clinical localization such as hygroma fluids or infected joints. While the microscopy samples include various lymph nodes, spleen, the pregnant or premature post parturient uterus, the udder, and male reproductive organs ${ }^{6}$. At the research site, mostly culturing tests are used to diagnose brucellosis. Culturing of Brucella from blood is useful in the case of bacteremia, which does not always exist but culturing milk gives a positive response to show the presence of Brucella. Samples of liver, udder, lymph nodes, spleen, and other organs used for culturing the purpose of brucellosis. Phenotypic characters including $\mathrm{CO}_{2}$ requirement, phage typing, and biochemical tests, are of great deals while using culture techniques for the identification of Brucella organisms and other problems in culturing are time-consuming, trained interne and applications of bio-safety ${ }^{7}$. To culture brucella, broth or agar can prepare from powder media. Solid media, including tryptose agar, trypticase soy agar, and dextrose agar are used to identify and isolate Brucella at the primary level. However, species like B. Hovis and $B$. canis can be cultured in media by the addition of 5-10\% sterile bovine or equine serum to it ${ }^{8}$. The optimum $\mathrm{pH}$ for the growth of Brucella is 6.6-7.4, whereas, optimum growth temperature ranges from 36 to $38^{\circ} \mathrm{C}^{9}$. Growth of other microbes and contaminants can be prevented using selective media such as Kuzdas and Morse and Farrell,s Morse 5,10.

Farrell's medium has some drawbacks because some of Brucella strains such as B. melitensis, B. ovis, and $B$. abortus cannot show healthy growth. Therefore, Thayer- Martin medium is slightly modified and then used in combination with Farrell's medium to get better growth of these Brucella species ${ }^{2}$.

\section{MOLECULAR METHODS}

The molecular procedure often based on PCR amplification is dominantly used for identification and typing to reduce the problem and hurdles of microbiological testing ${ }^{11}$. DNA isolation is an initial and essential step of PCR as its feature has a considerable impact on method sensitivity ${ }^{12}$. Initially, for bacterial determination, PCR has been developed ${ }^{13}$. Also, now, these processes are applied for the identification of brucellosis in humans and animals' clinical samples. The use of a single pair of primer act to the bacterial DNA sequence, such as 16 S-23s RNA operon, 15711 or BCSP31 genes with PCR is a reliable technique for the detection of brucellosis ${ }^{14}$. Using a mixture of some primer's pairs for magnification of BCSP31, OMP2B, OMP31 genes, encoding the external membrane proteins. It is easy to detect the four Brucella species: B. melitensis, B. suis, B. abortus and $B$. canis. The mixture of seven PCR reactions is another to allocate favoritism between brucella six species. PCR techniques used for the detection of some Brucella abortus biovars, which differentiated between S19 and RB51 strain of B. abortus and allowed for vaccination against pathogenic strain ${ }^{15}$.

\section{Multiplex PCR}

To boost the affective prevention and of brucellosis, a quick and precise method is required. Several studies have developed a PCR based assay for the differentiation of Brucella species. It has been revealed that the two multiplex PCR, called AMOS (B. abortus, B. melitensis, B. ovis and B. suis) and Bruce-ladder PCR assay can discriminate most of Brucella species such as marine mammal and vaccine strain B. abortus RB51, B. abortus S19 and B. melitensis 16. It allowed identification evidence of the four of Brucella species (B. abortus, B. melitensis, B. ovis and B. suis) and was titled AMOS PCR for the main correspondence of species name. AMOS PCR cannot detect the similar species single biovar but identify just the pair biovars of each of the same species, sooner after this technique has been promoted to differentiate more biovar and recognize brucella S 19 RB51 vaccine strain ${ }^{16,17}$. Moreover, as the PCR system convey high contamination risk and needs equipment for visualization, it is less favorable for routine diagnosis purpose. So real-time PCR systems have been established that are quicker and less prone to contamination and thus use more clinically.

\section{Real-time PCR}

The real-time PCR method is highly specific, sensitive, reproducible and quicker than the conventional PCR. The quantitative real-time (qRT) PCR permits both identification and quantification of the PCR product in real-time, but it is synthesized ${ }^{18}$. It has also been possible to differentiate the species and even at the biovar level through real-time PCR. This technique can be used for the quick diagnosis of chronic serologically positive brucellosis and for acute brucellosis when blood and serum samples of recognized clinical presentations are examined ${ }^{19}$. These assays are developed for targeting 16 S-23 S internal transcribed spacer region (ITC) and the genes coding omp25 and omp31, bcsp31, and IS711 ${ }^{20}$. For the detection of bacteria at the genus level, the bcsp31 gene target can be suggested. Species-specific recognition verifying the initial diagnosis by second gene target such as IS711 21 (Table 1). Many multiplex 
real-time PCR methods are developed for the immediate identification of Mycobacterium tuberculosis complex (MTC) and Brucella species. These methods amplify the IS711, bcsp31 and omp genes for the identification of Brucellas species and target the IS6110, senX3-regX3 and cfp31 genes for the recognition of the MTC $^{22}$. Sanjuan-jimenez et al. revealed three molecular targets of MTC (senX3-regX3, cfp31, IS6110) and three molecular targets (bcs31, IS711, omp2a) of Brucella for their instantaneous identification by a multiplex real-time PCR ${ }^{23-25}$. However, the sensitivity and specificity of PCR for Brucella differ between laboratories, and hence, standardization is needed.

\section{Serological diagnosis}

Several serodiagnosis methods are found for the determination of brucellosis 26. However, some of the tests are satisfactory sensitive and specific like indirect enzyme-linked immunosorbent assay (iELISA), competitive enzyme-linked immunosorbent assay (c- ELISA), Milk ring test, complement fixation test (CFT) and the fluorescence polarization assay (FPA) ${ }^{26,27}$. In each and every epidemiological situation, no single serological test is sufficient, all of which have limitations, particularly when it comes to screening individual animals Fluorescence polarization assay (FPA), Complement fixation test (CFT) and ELISA are considered more suitable for international trade than serum tube agglutination test (SAT). The buffered Brucella antigen tests (BBATs), i.e., the Rose Bengal Test (RBT) and the buffered plate agglutination test (BPAT), as well as the ELISA and the FPA, are sufficient screening tests for brucellosis control at the national or local level ${ }^{28}$. If necessary, positive reactions can be retested using an appropriate confirmatory strategy.

\section{Agglutination test}

Serological diagnosis of brucellosis first completed through an agglutination test ${ }^{29}$. The primary agglutination antibodies IgM and IgG2 detected through these tests similar to serum agglutination test $(\mathrm{SAT})^{30}$. Due to cross-reaction by IgM antibodies created in the competition of $B$. abortus sequences and other closely to Brucella species, therefore, its sensitivity is good, and specificity is low ${ }^{31}$. This test was rejected for international trading.

\section{Antiglobulin (Coombs) test}

The direct Coombs test is also known as the direct antiglobulin test (DAT) was the first time discovered by Coombs, Mourant, and Race in 1945 and is still an essential assay for the diagnosis of autoimmune hemolytic anemia (AIHA. The DAT can identify complement (C3) and RBC-bound IgG that opsonizes $\mathrm{RBCs}^{32}$. The serum agglutination test gives negative or suspected results, so a Coombs test used for confirmation of results. Due to the advantage of this test to detect incomplete antibodies of IgG types that combine with cellular antigens, this test is used for the epidemiological study but does not increase agglutination reaction (Table 1). To save time, this test modified to a microtiter plate set up. The limitation of this test it is not suggested for the diagnosis of vaccinated animals ${ }^{11}$.

\section{The 2-mercaptoethanol test}

The 2-MET are two forms that use either 2mercaptoethanol ${ }^{33}$ or dithiothreitol ${ }^{34}$. Dithiothreitol has recommended, because of the toxicity of 2mercaptoethanol. The disulfide of IgM is being condensed to the manometric molecule and unable to agglutination essentially calculate IgG unable to agglutinate. However, IgG can also be decreased in the procedure, providing false-negative results (Table 1). Though in general, reduction of IgM increases specificity ${ }^{35}$. The test not suggested for the global trade due to not eradication vaccinal antibodies. The 2 -MET is, however, used prominently for national control and eradication programs ${ }^{36}$.

\section{Buffered plate agglutination test (BPAT)}

The BAPT test was developed to detect Brucella spp antibody. BPAT is an easy cheap and uniform agglutination test. It utilized antigen at $\mathrm{pH}$ of 3.65, which is prepared from B. abortus $\mathrm{S} 119.3$ whole cells dyed with crystal violet and brilliant green colors. The test is responsible for false-positive results because of the prozoning effect and vaccinal antibodies ${ }^{36}$. Due to the reduction of non-specific test reactions, this test is very beneficial. It has directed for IgG testing ${ }^{37}$.

\section{Brucellin allergic skin test (BAST)}

The skin test is an allergic test that measures Brucella spp's unique cellular immune response. Brucellin allergic skin test (BAST) based on a delayed-type hypersensitivity reaction with a maximum sensitivity at 72 hours post-inoculation. This delayed type of hypersensitivity reaction is measured at the site of inoculation by the increase in skin thickness. The test is specific to complement serological tests for the diagnosis of bovine brucellosis, and thus decrease the figure of false-positive reactions significantly by distinguishing brucellosis from other cross-reacting organisms ${ }^{27}$. 
The test is more specific to RBPT and CFT in conditions of its specificity (exceeding 99\%). The skin test is highly specific, but its weak sensitivity makes it a good herd test, but not an individual certification test. Thus, it is often suggested for use at the herd level as a positive test in unvaccinated animals ${ }^{38}$.

\section{Complement fixation tests}

The IgM isotypes incompletely damaged during the inactivation process, so the CFT test mostly detects the IgG isotypes antibody. After the IgM type, the antibodies IgG1 types usually appear. The SAT and CFT best performed the control and surveillance of the disease. The test indicates an association with the recovery of Brucella from artificial recovery or naturally infected animals. Although the test is rapid and precise, it does not permit differentiation between antibodies due to infection from vaccinal antibodies 39 (Table 1). Other hurdles consist of a high figure of reagents and controls required to perform the test. Moreover, each time the assay is set up, a high number of titrations are necessary, and an explanation of the results is subjective due to variation in procedures ${ }^{40}$. Rarely, there is direct activation of complement by serum (anti-complementary activity) and the incapability of the test to be agreeable for use with hemolyzed serum samples. The laborious nature of this test and the need for highly- trained personnel and suitable laboratory facilities make the CFT less ideal for use in developing countries ${ }^{31}$. The complement fixation test may give false adverse reactions because the antibodies of IgG2 type obstruct the complement fixation. Despite all these problems, the complement fixation test is broadly used analysis because it is a most acceptable and specific serological test for the diagnosis of brucellosis, so it is a suggested test for international trade $^{41}$.

\section{MILK RING TEST (MRT)}

Fleischer developed a milk ring test (MRT) in $1937^{42}$. Fleischer promoted adoption of the serum agglutinations test to identify the accurateness of antibodies against Brucella species in milk named the MRT. It is suggested as a screening test to check Brucellosis is bulk tank milk ${ }^{43}$. The Milk ring test (MRT) is mainly an agglutination test done by cream or whole milk. Hematoxylin Brucella stained cells are added to milk and incubated to occur the reaction. Through the Fc portion of a fat molecule, the immunoglobulins present in the milk attached to fat globules ${ }^{44}$. MRT detects the IgM and IgA immunoglobulins. This test may be useful for an individual animal or to pooled milk samples by using the maximum volume of milk, comparative to the pool size ${ }^{3}$. In the milk ring test, the abnormal milk caused a false adverse reaction due to mastitis, milk from the late lactation, and due to the presence of colostrum ${ }^{45}$. Due to the low concentration of lacteal antibodies or lacking fat, clustering, factors in milk may also cause a false-negative result. Despite all these problems, the milk ring test is very successful, it is the method of choice in dairy herds, and it is a low-cost screening test as compared to other ${ }^{46}$.

\section{Primary Binding Assays}

Primary binding tests directly measure the interaction of antibodies and antigens while traditional serological tests, such as acidified agglutination tests or complementary fixation tests (CFTs), measure secondary phenomena such as agglutination or complementary activation.

The first binding assay technique developed due to some limitations in conventional methods of Brucella diagnosis. This test can find the humoral antibodies to Brucella species very rapidly and accurately ${ }^{47}$. Due to a short time of exposure, the vaccine has low efficiency, so it eliminates very soon by the immune system, but when a natural antigen enters the host has long exposure and has high energy and not removed by the immune system ${ }^{48}$. Therefore, to defeat this problem, the fluorescent polarization assay (FPA) and a competitive enzyme-linked immunosorbent assay were developed (cELISA). These tests can differentiate vaccinated animals or animals affected by crossreacting microorganisms like Escherichia coli O: 116 and O: 157 , Salmonella Urbana O: 30 , and Yersinia enterocolitica serotype nine from naturally- infected animals. Because of these capabilities, it is possible to decrease the amount of false-positive reactions ${ }^{49}$.

\section{Lateral Flow Assay (LFA)}

The simplified ELISA technique known as lateral flow assay (LFA) is used to detect antibodies of a specific antigen in samples of blood, serum, and milk. The method based on the attachment of antibodies specified to immobilized antigen on a strip (cellulose membrane matrix) that is involved in detecting specific IgM and IgG antibodies in all stages of the diseases ${ }^{3}$. The main advantage of this technique that it does not require any electrical equipment, but the only refrigerator is used to store the test kits, and this technique is limited in the formation of visible bands because of many ingredients in reaction ${ }^{50}$. 
Table 1: Comparisons of different diagnostic techniques

\begin{tabular}{|c|c|c|}
\hline Techniques & Advantage & Disadvantage \\
\hline Serum agglutination test & $\begin{array}{l}\text { Safe, inexpensive, and appropriate for primary } \\
\text { screening }\end{array}$ & $\begin{array}{l}\text { Cross-reactivity with other } \mathrm{mi}- \\
\text { croorganisms, } \\
\text { false-negative results in the early } \\
\text { stages of infection, and } \\
\text { prozone phenomenon }\end{array}$ \\
\hline ELISA & $\begin{array}{l}\text { Highly sensitive and specific, rapid, simple, and } \\
\text { capable } \\
\text { of distinguishing between acute and chronic } \\
\text { stages }\end{array}$ & Cross-reactivity \\
\hline Conventional culture & Gold standard and specificity & $\begin{array}{l}\text { Time consuming, insensitive or low } \\
\text { sensitive, and posing } \\
\text { a risk for laboratory staff }\end{array}$ \\
\hline $\begin{array}{l}\text { Coombs antiglobulin } \\
\text { agglutination test }\end{array}$ & Sensitive for relapsing and chronic brucellosis & $\begin{array}{l}\text { Labor-intensive and time consum- } \\
\text { ing }\end{array}$ \\
\hline Lateral flow assay & Easy, rapid, sensitive, and specific & $\begin{array}{l}\text { Expensive and possibility of cross- } \\
\text { reactivity }\end{array}$ \\
\hline Complement fixation test & Sensitive and specific & \\
\hline 2-Mercaptoethanol & $\begin{array}{l}\text { A confirmatory test that allows selective quantifi- } \\
\text { cation of } \\
\text { IgG anti-Brucella }\end{array}$ & $\begin{array}{l}\text { Toxicity of mercaptoethanol, the } \\
\text { possibility of IgG } \\
\text { degradation by the 2-ME, which } \\
\text { may lead to false } \\
\text { negative results }\end{array}$ \\
\hline $\begin{array}{l}\text { Fluorescence polarization } \\
\text { immunoassay }\end{array}$ & $\begin{array}{l}\text { Highly sensitive and specific, and capable of } \\
\text { distinguishing between acute and chronic stages }\end{array}$ & $\begin{array}{l}\text { Costly, need of trained laboratory } \\
\text { technicians, and } \\
\text { expensive equipment }\end{array}$ \\
\hline $\begin{array}{l}\text { Rose Bengal plate } \\
\text { agglutination test }\end{array}$ & & $\begin{array}{l}\text { Cross-reactivity with the antibodies } \\
\text { of other } \\
\text { microorganisms, false-negative } \\
\text { results in the early stages } \\
\text { of infection, and prozone phe- } \\
\text { nomenon }\end{array}$ \\
\hline PCR & $\begin{array}{l}\text { Rapid and accurate; can be performed on blood, } \\
\text { serum, } \\
\text { CSF, and other clinical samples; can yield positive } \\
\text { results } \\
\text { as early as } 10 \text { days after inoculation }\end{array}$ & $\begin{array}{l}\text { Expensive equipment, genus spe- } \\
\text { cific Brucladder has low } \\
\text { detection limit, and works only on } \\
\text { pure cultures }\end{array}$ \\
\hline Real-time PCR & $\begin{array}{l}\text { Highly sensitive, specific, and rapid; can be per- } \\
\text { formed on } \\
\text { blood, serum, CSF and other clinical samples }\end{array}$ & Expensive equipment \\
\hline
\end{tabular}


Figure 1: Milk ring test result.

\section{Fluorescence Polarization Assay (FPA)}

Fluorescence Polarization Assay (FPA) is a homogeneous immunoassay. Homogenous immunoassays are single-step assays that do not require repeated washing steps to remove unbound reactants as with conventional primary binding assays. This technique works on the principle of excitation of fluorescent molecules using polarized light to emit it, the emission of light in the solution is inversely proportional to the rotation speed of the molecules. This speed is associated with the viscosity of the solution, temperature and gas constant, and molecular volume ${ }^{51}$. In the serology of brucellosis, a component of $\mathrm{O}$ polysaccharide (OPS) of smaller molecular weight is labeled with fluorescein isothiocyanate to use as an antigen. In different samples of serum, milk, and blood if antibodies are present, they are rotated at a reduced rate because of presences of antibodies ${ }^{52}$.

\section{Competitive Immunoassays}

This technique applied by using monoclonal antibody having a high affinity to antigen as compared to a cross-reacting antibody. This technique is mainly used because of its high specificity and involved in the detection of antibody isotypes (IgM, IgG1, IgG2, and $\operatorname{IgA}$ ). The limitation related to this technique is less sensitive than direct immunoassay ${ }^{53}$.

\section{Rose Bengal Plate Test (RBPT)}

This test is mostly used to diagnose brucellosis in sheep, goats, and buffalo, and it was the first time used by Morgan for Brucella-infected animals. It is an internationally recommended test for screening of Brucella detection in animals. The result obtained in a short time, but the limitation of this test is the sensitivity and specificity of RBPT antigen because of its cross-reactivity with other bacterial species such as $E$. coli O157, Vibrio cholera, and some Salmonella spp. The RBPT is spot agglutination technique, which we also called card test or buffered brucella antigen test ${ }^{27}$. In this test suspension of $B$. abortus, smooth cells are retained with Rose Bengal dye using a buffer of $\mathrm{Ph}$ 3.65. Low $\mathrm{Ph}$ is used to increase the sensitivity of test $^{53}$. The test can also be used to show the presence of IgM, IgG1, and IgG2 antibodies at neutral PH. This test may result in false-negative results, but it also results in false-positive results due to the significant part to reactions with IgM in animals with the previous vaccination. However, this test occurs actively right when the organisms are not vaccinated previously, and the animal exposed to Brucella species.

\section{CONCLUSION}

The diagnosis of brucellosis in humans and livestock is not an easy task. The "gold standard" of Brucella identification is the recovery of the agent from the host, but it is time consuming and laborious method. Which can be done in highly equipped laboratories. For the diagnosis of brucellosis serological test has been developed more than a century ago, but still, a comprehensive test has not been established. The traditional serological procedure for the diagnostic of brucellosis is based on the recognition of antibodies, specific to surface LPS. Which is responsible for the low specificity of the test results. An alternative way to solve this problem is the identification of antibodies to Brucella specific proteins. It appears that there are 

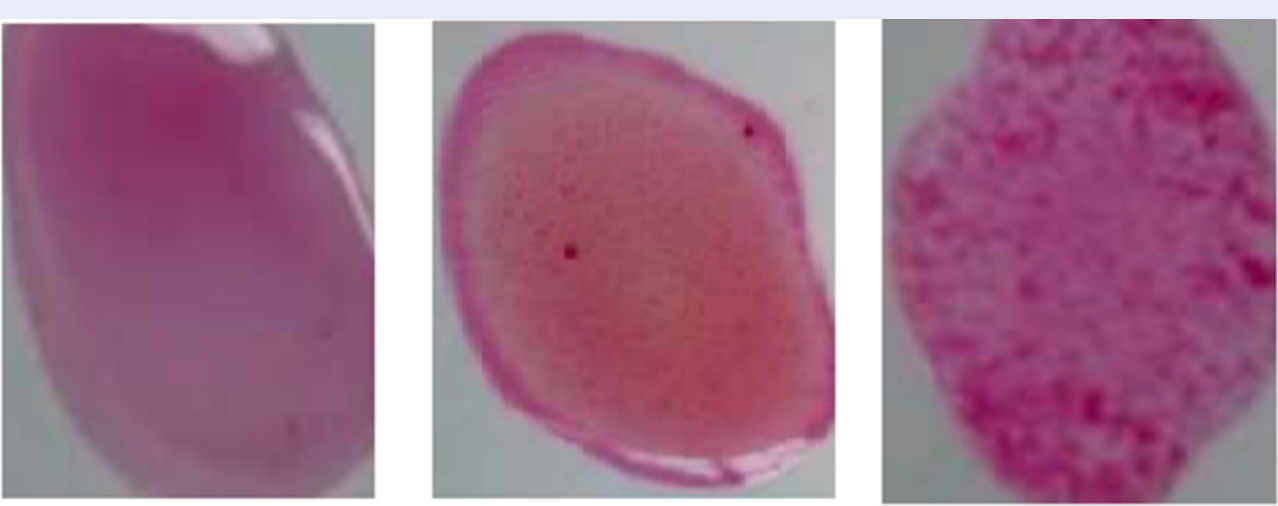

Figure 2: Rose Bengal plate indicating agglutination. Right strong agglutination, moderate, noagglutination.

no sole immunodominant proteins, but to date, proteomic techniques permit analysis of whole Brucella proteome to determine a series of such proteins. The systemic biology methods may not only effectively use in the diagnosis of brucellosis, but can also develop the understanding of fundamental biological processes in the Brucella infected body, including those leading to the large variability in the immune response. The molecular diagnosis method is the most commonly used for the diagnosis of disease. Because it is costeffective, safe, and rapid as compared to bacteriological tests. PCR-base techniques for the identification of Brucella in biological samples are becoming an essential tool for the diagnosis of brucellosis at biovar and species levels. Although, PCR analysis of the sample should be fully authenticated earlier, the daily use in laboratory testing for brucellosis. For the detection of Brucella DNA, the most promising method is realtime multiplex PCR. Also, the next-generation techniques can be used for organism diagnosis. Still, they are costly but becoming more accessible and popular. Recently, for the recognition and genotyping of Brucella, the mass spectrometry approach was recommended. This method provides reliable and fast identification of organisms at the species level, but it needed special sophisticated equipment, which is only available in big laboratories. All of the above methods can be very accurate and sensitive, but they can't be utilized in the field condition such as farms, where laboratory testing is available. Meanwhile, these are more suitable for the detection of humans Brucella, but not in livestock.

Therefore, we believe that the development of a diagnostic test for brucellosis is associated with an easy-touse, quick test for initial diagnosis and high sensitivity and specific method for further laboratory testing.

\section{ABBREVIATIONS}

BBATs: buffered Brucella antigen tests BPAT: buffered plate agglutination test FPA: Fluorescence polarization assay i-ELISA: enzyme-linked immunosorbent assay ITC: transcribed spacer region

LFA: lateral flow assay

MRT: milk ring test

MTC: Mycobacterium tuberculosis complex PCR: polymerase chain reaction

qRT: quantitative real-time

RBPT: Rose Bengal Plate Test

RBT: Rose Bengal Test

SAT: serum tube agglutination test

ZN: Ziehl-Neelsen

\section{CONFLICT OF INTEREST}

The author shows no conflict of interest.

\section{AUTHORS' CONTRIBUTIONS}

All the authors have equally contributed to this work.

\section{REFERENCES}

1. Abdelbaset AE, Abushahba MF, Hamed MI, Rawy MS. Serodiagnosis of brucellosis in sheep and humans in Assiut and ElMinya governorates, Egypt. International journal of veterinary science and medicine. 2018;6(S1):S63-S7.

2. Poester FP, Nielsen K, Samartino LE, Yu WL. Diagnosis of brucellosis. The Open Veterinary Science Journal. 2010;4(1). Available from: 10.2174/1874318801004010046.

3. Nielsen K, Yu WL. Serological diagnosis of brucellosis. Prilozi. 2010;31(1):65-89. PMID: 20703184.

4. Marin G, Gamba RJ. A new measurement of acculturation for Hispanics: The Bidimensional Acculturation Scale for Hispanics (BAS). Hisp J Behav Sci. 1996;18(3):297-316. Available from: 10.1177/07399863960183002.

5. Farrell ID. The development of a new selective medium for the isolation of Brucella abortus from contaminated sources. Res Vet Sci. 1974;16(3):280-6. PMID: 4369280. Available from: 10.1016/S0034-5288(18)33726-3. 
6. Acha PN, Szyfres B. Zoonoses and communicable diseases common to man and animals. vol. Volume 580. Pan American Health Org; 2003.

7. Ismail AA. Knowledge, Attitudes and Practices Associated with Brucellosis in Small-holder Dairy Farms in Suburbs of Khartoum State, Sudan. EC Veterinary Science. 2019;4:24150.

8. Atlas R, Snyder J. Reagents, stains, and media: bacteriology. Manual of Clinical Microbiology. American Society of Microbiology; 2015.

9. Pacheco-Montealegre $M$, Patiño RE, Torres $L$, Jiménez $S$, Rodriguez JL, Caro-Quintero A. High quality draft genome of Brucella abortus strain Col-B012, isolated from a Holstein cattle in Nariño Colombia, brings new insights into the diagnosis and the epidemiology of biovar 4 strains. PeerJ Preprints; 2017.

10. Kuzdas CD, Morse EV. A selective medium for the isolation of brucellae from contaminated materials. J Bacteriol. 1953;66(4):502-4. PMID: 13096514. Available from: 10.1128/ JB.66.4.502-504.1953.

11. Minda AG, Gezahegne MK. A review on diagnostic methods of brucellosis. J Vet Sci Technol. 2016;7(3).

12. Moussa I, Omnia M, Amin A, Selim S. Evaluation of the currently used polymerase chain reaction assays for molecular detection of Brucella species. Afr J Microbiol Res. 2011;5(12):1511-20. Available from: 10.5897/AJMR11.054.

13. Boschiroli ML, Ouahrani-Bettache $S$, Foulongne $V$, MichauxCharachon S, Bourg G, Allardet-Servent A, et al. The Brucella suis virB operon is induced intracellularly in macrophages. Proc Natl Acad Sci USA. 2002;99(3):1544-9. PMID: 11830669. Available from: 10.1073/pnas.032514299.

14. Godfroid J, Nielsen K, Saegerman C. Diagnosis of brucellosis in livestock and wildlife. Croat Med J. 2010;51(4):296-305. PMID: 20718082. Available from: $10.3325 / \mathrm{cmj} .2010 .51 .296$

15. Yu WL, Nielsen K. Review of detection of Brucella spp. by polymerase chain reaction. Croat Med J. 2010;51(4):306-13. PMID: 20718083. Available from: $10.3325 / \mathrm{cmj} .2010 .51 .306$.

16. Kang SI, Her M, Kim JW, Kim JY, Ko KY, Ha YM, et al. Advanced multiplex PCR assay for differentiation of Brucella species. Appl Environ Microbiol. 2011;77(18):6726-8. PMID: 21666028. Available from: 10.1128/AEM.00581-11.

17. Kattar MM, Zalloua PA, Araj GF, Samaha-Kfoury J, Shbaklo $\mathrm{H}$, Kanj SS, et al. Development and evaluation of realtime polymerase chain reaction assays on whole blood and paraffin-embedded tissues for rapid diagnosis of human brucellosis. Diagn Microbiol Infect Dis. 2007;59(1):23-32. PMID: 17532591. Available from: 10.1016/j.diagmicrobio.2007.04. 002.

18. Bounaadja $L$, Albert $D$, Chénais $B$, Hénault $S$, Zygmunt MS, Poliak S, et al. Real-time PCR for identification of Brucella spp.: a comparative study of IS711, bcsp31 and per target genes. Vet Microbiol. 2009;137(1-2):156-64. PMID: 19200666. Available from: 10.1016/j.vetmic.2008.12.023.

19. Dahouk SA, Nöckler K, Scholz HC, Pfeffer M, Neubauer $H$, Tomaso $\mathrm{H}$. Evaluation of genus-specific and species-specific real-time PCR assays for the identification of Brucella spp. Clin Chem Lab Med. 2007;45(11):1464-70. PMID: 17970716. Available from: 10.1515/CCLM.2007.305.

20. Gee JE, De BK, Levett PN, Whitney AM, Novak RT, Popovic T. Use of $16 \mathrm{~S}$ rRNA gene sequencing for rapid confirmatory identification of Brucella isolates. J Clin Microbiol. 2004;42(8):3649-54. PMID: 15297511. Available from: 10. 1128/JCM.42.8.3649-3654.2004

21. Huber B, Scholz HC, Lucero N, Busse HJ. Development of a PCR assay for typing and subtyping of Brucella species. Int J Med Microbiol. 2009;299(8):563-73. PMID: 19560966. Available from: 10.1016/j.ijmm.2009.05.002.

22. Dahouk SA, Nöckler K, Tomaso H, Splettstoesser WD, Jungersen G, Riber $U$, et al. Seroprevalence of brucellosis, tularemia, and yersiniosis in wild boars (Sus scrofa) from north-eastern Germany. J Vet Med B Infect Dis Vet Public Health. 2005;52(10):444-55. PMID: 16364020. Available from: 10.1111/j.1439-0450.2005.00898.x.
23. Dahouk SA, Flèche PL, Nöckler K, Jacques I, Grayon M, Scholz $\mathrm{HC}$, et al. Evaluation of Brucella MLVA typing for human brucellosis. J Microbiol Methods. 2007;69(1):137-45. PMID: 17261338. Available from: 10.1016/j.mimet.2006.12.015.

24. Dahouk SA, Sprague LD, Neubauer H. New developments in the diagnostic procedures for zoonotic brucellosis in humans. Rev Sci Tech. 2013;32(1):177-88. PMID: 23837375. Available from: 10.20506/rst.32.1.2204.

25. Özdemir M, Feyzioğlu B, Kurtoğlu MG, Doğan M, DağıHT, Yüksekkaya, et al. A comparison of immuncapture agglutination and ELISA methods in serological diagnosis of brucellosis. Int J Med Sci. 2011;8(5):428-32. PMID: 21814476. Available from: 10.7150/ijms.8.428.

26. Ducrotoy MJ, Conde-Álvarez R, Blasco JM, Moriyón I. A review of the basis of the immunological diagnosis of ruminant brucellosis. Vet Immunol Immunopathol. 2016;171:81-102. PMID: 26964721. Available from: 10.1016/j.vetimm.2016.02. 002.

27. Manish K, Chand P, Rajesh C, Teena R, Sunil K. Brucellosis: an updated review of the disease. Indian J Anim Sci. 2013;83(1):3-16.

28. Ali S, Ali Q, Neubauer H, Melzer F, Elschner M, Khan I, et al. Seroprevalence and risk factors associated with brucellosis as a professional hazard in Pakistan. Foodborne Pathog Dis. 2013;10(6):500-5. PMID: 23560424. Available from: 10.1089/ fpd.2012.1360.

29. Clavijo E, Díaz R, Anguita A, García A, Pinedo A, Smits HL. Comparison of a dipstick assay for detection of Brucella-specific immunoglobulin $M$ antibodies with other tests for serodiagnosis of human brucellosis. Clin Diagn Lab Immunol. 2003;10(4):612-5. PMID: 12853393.

30. Praud $A$, Durán-Ferrer $M$, Fretin $D$, Jaÿ $M, O^{\prime}$ Connor $M$, Stournara $A$, et al. Evaluation of three competitive ELISAs and a fluorescence polarisation assay for the diagnosis of bovine brucellosis. Vet J. 2016;216:38-44. PMID: 27687924. Available from: 10.1016/j.tvjl.2016.06.014.

31. Segel GB, Lichtman MA. Direct antiglobulin (") test-negative autoimmune hemolytic anemia: a review. Blood Cells Mol Dis. 2014;52(4):152-60. PMID: 24411920. Available from: 10.1016/ j.bcmd.2013.12.003.

32. Rose JE, Roepke MH. PHYSICOCHEMICAL STUDIES ON POSTVACCINAL BRUCELLA AGGLUTININS IN BOVINE SERUM. Am J Vet Res. 1964;25:325-8. PMID: 14125895.

33. Klein GC, Behan KA. Determination of brucella immunoglobulin $\mathrm{G}$ agglutinating antibody titer with dithiothreitol. J Clin Microbiol. 1981;14(1):24-5. PMID: 7263851. Available from: 10.1128/JCM.14.1.24-25.1981.

34. Gupte S, Kaur T. Determination of brucella immunoglobulin $\mathrm{G}$ agglutinating antibody titer with dithiothreitol. Journal of clinical microbiology. 2015;14(1):24-5.

35. Nielsen K. Diagnosis of brucellosis by serology. Vet Microbiol. 2002;90(1-4):447-59. PMID: 12414164. Available from: 10.1016/S0378-1135(02)00229-8.

36. de Glanville WA, Conde-Álvarez R, Moriyón I, Njeru J, Díaz R, Cook EA, et al. Poor performance of the rapid test for human brucellosis in health facilities in Kenya. PLoS Negl Trop Dis. 2017;11(4):e0005508. PMID: 28388625. Available from: 10. 1371/journal.pntd.0005508.

37. Bercovich Z, Güler L, Baysal T, Schreuder B, van Zijderveld F. Evaluation of the currently used diagnostic procedures for the detection of Brucella melitensis in sheep. Small Rumin Res. 1998;31(1):1-6. Available from: 10.1016/S0921-4488(98) 00111-4.

38. Zamri-Saad M, Kamarudin MI. Control of animal brucellosis: the Malaysian experience. Asian Pac J Trop Med. 2016;9(12):1136-40. PMID: 27955740. Available from: 10. 1016/j.apjtm.2016.11.007.

39. Getachew T, Getachew G, Sintayehu G, Getenet M, Fasil A. Control of animal brucellosis: the Malaysian experience. Asian Pacific journal of tropical medicine. 2016;9(12):1136-40. Available from: 10.1155/2016/8032753. 
40. Manual OT. Bayesian estimation of sensitivity and specificity of rose bengal, complement fixation, and indirect ELISA tests for the diagnosis of bovine brucellosis in Ethiopia. Veterinary Medicine International. 2009;2016.

41. Manual OT. Bovine brucellosis. Retrieved February 02, 2012 fromhttp. 2009.

42. Ali S, Akhter $\mathrm{S}$, Neubauer $\mathrm{H}$, Melzer F, Khan I, Ali Q, et al. Serological, cultural, and molecular evidence of Brucella infection in small ruminants in Pakistan. J Infect Dev Ctries. 2015;9(5):470-5. PMID: 25989166. Available from: 10.3855/ jidc. 5110 .

43. Morgan WJ. The serological diagnosis of bovine brucellosis Vet Rec. 1967;80(21):612-20. PMID: 6067975. Available from: 10.1136/vr.80.21.612.

44. Spitsberg VL. Invited review: bovine milk fat globule membrane as a potential nutraceutical. J Dairy Sci. 2005;88(7):2289-94. PMID: 15956291. Available from: 10 3168/jds.S0022-0302(05)72906-4.

45. Al-Mariri A, Haj-Mahmoud N. Detection of Brucella abortus in bovine milk by polymerase chain reaction. Acta Vet Brno. 2010;79(2):277-80. Available from: 10.2754/avb201079020277.

46. Corbel MJ. Brucellosis in humans and animals. World Health Organization; 2006.

47. El-Eragi A, Salih MH, Alawad MF, Mohammed K. Evaluation of immunochromatographic assay for serodiagnosis of bovine brucellosis in Gezira State, Sudan. Vet World. 2014;7(6):395-7.
Available from: 10.14202/vetworld 2014.395-397.

48. Nielsen K, Cherwonogrodzky JW, Duncan JR, Bundle DR Enzyme-linked immunosorbent assay for differentiation of the antibody response of cattle naturally infected with Brucella abortus or vaccinated with strain 19. Am J Vet Res. 1989;50(1):5-9. PMID: 2465711.

49. Pedersen K, Bauer NE, Olsen S, Arenas-Gamboa AM, Henry AC, Sibley TD, et al. Identification of Brucella spp. in feral swine (Sus scrofa) at abattoirs in Texas, USA. Zoonoses Public Health. 2017;64(8):647-54. PMID: 28391650. Available from: 10.1111/ zph. 12359.

50. Chin CD, Linder V, Sia SK. Commercialization of microfluidic point-of-care diagnostic devices. Lab Chip. 2012;12(12):211834. PMID: 22344520. Available from: $10.1039 / \mathrm{c} 21 \mathrm{lc} 21204 \mathrm{~h}$.

51. Jolley ME, Nasir MS. The use of fluorescence polarization assays for the detection of infectious diseases. Comb Chem High Throughput Screen. 2003;6(3):235-44. PMID: 12678702. Available from: 10.2174/138620703106298419.

52. O'Grady D, Byrne W, Kelleher P, O'Callaghan H, Kenny $\mathrm{K}$ Heneghan T, et al. A comparative assessment of culture and serology in the diagnosis of brucellosis in dairy cattle. Vet $\mathrm{J}$. 2014;199(3):370-5. PMID: 24507882. Available from: 10.1016/ j.tvjl.2014.01.008.

53. MacMillan AP, Greiser-Wilke I, Moennig V, Mathias LA. A competition enzyme immunoassay for brucellosis diagnosis. Dtsch Tierarztl Wochenschr. 1990;97(2):83-5. PMID: 2178906. 